\title{
Risk Management Practices and Financial Performance: The Case of Sultanate of Oman
}

Shima Hamdan AL Mamari*, Ahad Said AL Ghassani, Essia Ries Ahmed

Collage of Economics, Management and Information Systems, University of Nizwa, Oman

The main objective of this study is to test the relationship between risk management practices and a bank's financial performance. This is a quantitative study, where the quantitative data was collected via secondary data. Data collection from the annual reports of eight banks listed on the Muscat Stock Exchange (MSX). In this research, data collected is analyzed using Structural Equation Modelling (SEM) with Partial Least Square PLS Software. The findings revealed that risk management is positively

OPEN ACCESS

ISSN 2548-3501 (online)

Edited by:

Tariq Tawfeeq Yousif Alabdullah

Correspondence 10946965@uofn.edu.om Received: 25 November 2021 Accepted: 26 January 2022

Published: 31 January 2022

Citation: Mamari, Ghassani and Ahmed (2022) Risk Management Practices and Financial Performance: The Case of Sultanate of Oman meaningful while avoiding risk. The findings pointed out that risk management has a significant relationship with the return of assets (ROA). This result indicates that management has a significant influence on banks performance (ROA). As well as, the findings found that risk management has no significant relation to return of equity $(\mathrm{ROE})$. This study is new in its kind to be applied in the Oman context via investigating the relation between its predictors of risk management practices' towards their impact on financial performance.

Keywords: Risk Management Practices, Financial Performance, Banks, Oman.

Tujuan utama dari penelitian ini adalah untuk menguji hubungan antara praktik manajemen risiko dengan kinerja keuangan bank. Penelitian ini merupakan penelitian kuantitatif, dimana data kuantitatif dikumpulkan melalui data sekunder. Pengumpulan data dari laporan tahunan delapan bank yang terdaftar di Muscat Stock Exchange (MSX). Dalam penelitian ini, data yang terkumpul dianalisis menggunakan Structural Equation Modeling (SEM) dengan Software PLS Partial Least Square. Temuan menunjukkan bahwa manajemen risiko bermakna positif sambil menghindari risiko. Temuan menunjukkan bahwa manajemen risiko memiliki hubungan yang signifikan dengan ROA. Hasil ini menunjukkan bahwa manajemen memiliki pengaruh yang signifikan terhadap kinerja bank (ROA). Selain itu, temuan menemukan bahwa manajemen risiko tidak terkait secara signifikan dengan (ROE). Ini jenis penelitian baru yang diterapkan dalam konteks Oman melalui penyelidikan hubungan antara prediktor praktik manajemen risiko terhadap dampaknya pada kinerja keuangan.

Keywords: Praktik Manajemen Risiko, Kinerja Keuangan, Perbankan, Oman. 


\section{INTRODUCTION}

The crisis of Financial management around the globe has proven that activities of risk management are necessary for organization that goal at sustaining client and shareholder patronage (Alabdullah, Ahmed, \& Nor, 2020; Olamide, Uwalomwa, \& Ranti, 2015; Abushammala, Alabdullah, \& Ahmed, 2015). Before now, risk management was not seen as a central component of the transaction of most companies in Oman (Alabdullah, \& Ahmed, 2020; Alyaarubi, Alkindi, \& Ahmed, 2021; Gani, Al Rahbi, \& Ahmed, 2021). In light of the developments that have contributed to increasing competition in global markets in the field of financial transactions, any bank is exposed to various banking risks that may lead to their collapse and deterioration of financial conditions (Bilal, \& Salim, 2016; Alabdullah, \& Ahmed, 2018). Oman has been able to put in place a stable risk management framework, especially credit risk management, in order to reduce unfavorable events (Alabdullah, \& Ahmed, 2020). The Credit risk of management is an important fraction of the banking loan operation. It is the risk of current and future profit Failure to implement the terms of any contract with the bank or any other performance as agreed upon may cause problems) Azam, 2019; Alabdullah, Ahmed, \& Nor, 2019). Such as losing a loan outstanding in part or in full, Due to credit events (risk of default), which may be caused by bankruptcy and non-payment of outstanding obligations Refusal/ postponement or change of credit rating and restructuring again, which are reasons for the occurrence of problems in banks (Ogboi, \& Unuafe, 2013; Alabdullah, Ahmed, \& Nor, 2018).

Financial risk is a difference in returns or unexpected changes in it that contribute negatively to the management of the financial organization and there are different types (Thottoli, Thomas, \& Ahmed, 2019a; Thottoli, Thomas, \& Ahmed, 2019b; Thottoli, Thomas, \& Ahmed, 2019c). The term financial risk refers to different types of financing risks, such as financial transactions that depend on loans, risks of delaying payments to companies, high exchange rates and currency changes. The main factor for these problems is the stock market and sudden declines, which are attributed to changes in assets that may be related to debt, which lead to a potential Lack of balance between responsibilities and obligations (Alsulmani, \& Ahmed, 2021; Ahmed, Alabdullah, \& Shaharudin, 2020). Therefore, we can understand that managing financial risks is an important matter to be taken care of as it is reflected in the financial performance of the bank. A great deal of empirical research has emerged in recent years about the effect of Managing financial risks on financial performance and its downsides. As these studies contributed to the definition of the importance and important role that the country financial system plays the cornerstone and jewel of the country's economy, and it is a financial mediator between countries and their development (Alia, \& Oudatb, 2020; Alabdullah, Laadjal, Ries, \& Al-Asadi, 2018).

In recent trends the global financial arena has had a major impact on the banking industry Around the world there is a need for one major mechanism for liquidity effective management in banks establishment (Hashim, Ries, \& Huai, 2019; Alabdullah, Ahmed, \& Muneerali, 2019). Thus, liquidity is the ability to generate sufficient money to pay financial obligations and liquidity in banks means that it is the ability to meet outstanding deposits (Alabdullah, Ahmed, \& Ahmed, 2021; Alabdullah, 2016a,b,c,d; Alabdullah, 2016b). According to Chowdhury (2014), the management of liquidity to financing for deficits, managing investing surpluses and developing the balance sheet to ensure that the bank works within specific regulatory limits. The ideal bank management is to ensure a balance between profitability liquidity and risk. Banks already necessitate liquidity because a large ratio of their liabilities is payable on demand (deposits) and thus the more liquid an asset is, the lower its return (Alabdullah, Ahmed, 2019; Alabdullah et al, 2014a,b, Alabdullah, Nor, \& Ahmed, 2018). The effective management of liquidity risk helps to ensure that the bank is able to meet cash flows Uncertain liabilities are influenced by external events and other factors (Alabdullah, \& Ahmed, \& Abushammala, 2020). Thus, liquidity risk management is of maximum importance because the lack of liquidity can have repercussions for one institution at the system level (Dzapasi, 2020; Ahmed, Abdul Rahim, Alabdullah, \& Thottoli, 2019). Risk management and financial performance are important factors in the stability of banks It contributes to economic growth, which may be reflected positively if troubles are avoided Where countries depend on their dealings and economic activity mainly on banks and economic transactions It is the level of development and advancement of the country, so it must be managed with a high level of accuracy (Harash, Alsaad, \& Ahmed, 2013; Alabdullah, 2021; Alabdullah, Ahmed, Almashhadani, Yousif, Almashhadani, Almashhadani, Putri, 2021). Some research has clarified the link inter risk of management and the financial performance of banks and its negative impact, and the accordingly, a group of the problems facing Omani banks, including the existence of a negative link between capital adequacy and financial management in Omani banks, as well as between debt and performance in Oman (Ahmed, Alabdullah, Shaharudin, \& Putri, 2020). It also includes the negative effects of delays and defaults in bank payments in the Gulf Cooperation Council countries due to support for the oil industry (Thottoli \& Ahmed, 2021; Ahmed, Alabdullah, Thottoli, \& Maryanti, 2020; Rao Al-Yahyaee \& Syed, 2007; Singh, Islam, Ahmed, \& Amran, 2019; Alabdullah, 2018, 2019). and there are effects related to financial management and liquidity in Omani banks Likewise, management of liquidity risk is of maximum importance because a lack of liquidity may have system-wide repercussions for a single institution (Alharthi, 2017; Ahmed, Alabdullah, Ardhani, \& Putri, 2021). Thus, the main goal of this study is to examine determine the link inter risk of management practices and bank's financial performance.

The remaining section of the study is organized as a literature review, theoretical framework, hypotheses, methodology, results and findings, conclusions, and recommendation. In this part, we will concentrate on previous studies from the past five years. The majority of studies found that there is an effect between financial risk and the instrument. For example, Alia, et al.. (2020) and Ahmed et al. (2017) its goal is to discover the influence of risks on the performance financial of recorded banks in the Bahrain. One of the most important findings of his research is that capital risk is the greatest important form of risk. The majority of studies found that there was an influence of management practices on performance. For example, Sleimi, (2020), Alabdullah \& Maryanti, 2021), the goal is the study the influence of the risk of management practices on the performance of Jordanian commercial banks. 
Most studies found analyzing the efficiency of performance. For example, Sukmana, Ajija, Salama, and Hudaifah, (2020) aim is to study the efficiency of the performance of traditional and Islamic rural banks in Indonesia, and one of the most important results of his research is that there is a positive impact on the location and the ratio of capital adequacy. Almagtome, and Abbas, (2020). Study indicates that there is a relationship between the company's values in the financial markets and investor behaviors and their impact on the financial of performance for Iraqi banks. The outcomes showed that there has a link and a correlation inter the total value of profits and revenues, which resulted in an increase in the name values and an increase in profits, which is positively reflected in the financial performance of the banks and their trades. The study conducted by Alfadli, and Rjoub, (2020) aims to know the impact of the special shifts in banks in the industry and the macroeconomics on the financial performance of banks in the Gulf Cooperation Council (GCC) countries. The results showed a negative relationship and significant effects of efficiency, diversification, liquidity, and credit risk, which are reflected in the capital. A study was done by Darwish, and Abdeldayem, (2019) which aims to study the relationship between risk management, business ethics, and the effect of its reputation on the financial performance of banks in their dealings in the Gulf Council also contributed to Where the score showed that there is a powerful link inter ethics and risk management, as positive results do not appear in the risk management process effectively if there is no good work ethic, which is positively reflected on workers inside banks. The study that he conducted Galdeano, Ahmed, Fati, Rehan, and Ahmed, (2019) which aims to find out how to improve performance financial in the financial sector and improve the relationship inter regulatory companies and the banking sector in Bahrain, which showed that there is a significant impact between financial performance and regulatory companies, as well as statistically link inter regulatory participation and financial performance in the bank. Pakurár, Haddad, Nagy, Popp, and Oláh,(2019) the study aims to investigate the impact of the relationships between internal control and financial performance in Jordanian banks. This study resulted in the existence of a relationship between internal control and between suppliers and customers and between Jordanian banks. The majority of studies found that there are risks due to an expansion in banking services. for example, Al Siyabi, Al Araimi, and Pandey, (2019) and aim are to examine the risks of microelectronic banking services in Oman. One of the most important findings of his research is to classify refuge risks as the maximum important. The majority of studies found that there is an influence of bilateral governance on the banking instrument. For example, Alabdullah and Ahmed, (2021), Nomran, and Haron, (2019), their objective is to discover the impact of the dual-board governance body on the performance of the Islamic bank in Southeast Asia and banks in the GCC countries. One of the most important findings of his research is that small banks have a very positive effect on the performance of multiple banks in Southeast Asia while their influence is not present in the GCC countries. Most found a relationship between responsibility and performance. For example, Maqbool, and Zameer (2018) the objective of this research is to examine the link between inter corporate social liability and financial performance in the Indian context. One of the most important findings of his research is that corporate social liability has a positive impact on the financial performance of Indian banks. Airout, and Airout, (2017) this study clarifies of the relationship between diversity and sustainability in the environmental and economic sector and the social dimension and its impact on the financial performance of Jordanian banks and its importance. The results indicate the existence of evidence of a relationship between sustainability and sustainability. Performance Financial sectors that are evaluated with the return on assets and stocks in Jordanian banks. Alharthi, (2017) the study aims to show the determinants of banks' financial performance, stability in transactions and achieving profits at three levels of return from assets, net interest and returns from stocks and their impact on the bank's financial performance. Where the study results indicated that banks in the Gulf Cooperation Council countries made good profits from their commitment to specific financial performance, which was in the Arab Spring crisis. We found that there is a link between administrative risks and the financial performances of the banks, for example Ahmed et al, (2014) and Tarawneh, (2016), a lesson The financial performance of that banks. The study aims to assess whether the commercial banks in Oman are related to the stability of the categories and their financial characteristics. And the impact of asset management and operational capacity of the bank and the ability of the bank on financial performance. It is the most important of his findings That a bank that owns capital, deposits or trusts, and high financial performance makes better profits than banks that do not possess high ratios of assets and financial performance. The study conducted by Salim, and Bilal, (2016) which aims to understand the relationship between financial liquidity and administrative risks of Omani banks and the impact of administrative risks on bank policies, showed that the results of the research showed that there is no link between liquidity, whether long-term or short-term liquidity, management risks, investment status, and the bank's tolerance to financial shocks. Surprising as there is no indication of any relationship. Also, this study conducted by Hassan Al-Tamimi, Miniaoui and Elkelish, (2015) indicates a negative relationship between management and banking risks in the terms of liquidity of risk, operational risk, and capital risk. The results of the study showed a negative relationship between risk management and banks, which comes on top of capital risk, followed by operational risk.

\section{Research Framework}

The framework of the study gives the basic structure in link to the dependent variable (financial performance), and the independent variable (risk management practices). The theoretical framework is developed to describe the link through the identified variables by way of a thorough literature review survey. Figure 1. below presents the proposed research framework of this study.

Figure 1: Research Framework 


\section{Relation Between Risk Management Practice And Bank's Financial Performance}

Alia, et al.. (2020) One of the most important findings of his research is that capital risk is the greatest important form of risk. The majority of studies found that there is an influence of bilateral governance on the banking instrument. Sleimi, (2020) Most of the studies found analyzing the efficiency of performance. Sukmana, Ajija, Salama, and Hudaifah,(2020) Most found a relationship between responsibility and performance. Almagtome, and Abbas, (2020) The majority of studies found that there are risks due to an expansion in banking services. Alfadli, and Rjoub, (2020) results showed a negative relationship and significant effects of efficiency, diversification, liquidity and credit risk, which are reflected in capital Darwish , and Abdeldayem, (2019) Where the scores showed there is a powerful link inter ethics and risk of management, as positive results do not appear in the risk management process effectively if there is no good work ethic, which is positively reflected on workers inside banks. Galdeano, Ahmed, Fati, Rehan, and Ahmed, (2019) which showed that there is a significant impact between financial performance and regulatory companies, as well as a significant statistical relationship inter regulatory participation and financial performance in the bank. Pakurár, Haddad, Nagy, Popp, and Oláh,(2019) This study resulted in the existence of a relationship between internal control and between suppliers and customers and between Jordanian banks. Al Siyabi, Al Araimi, and Pandey, (2019) The majority of studies found that there is an effect between financial risk and the instrument. Nomran, and Haron, (2019) One of the most important findings of his research is that small banks have a very positive influence on the performances of multiple banks in Southeast Asia while their influence is not present in the GCC countries. The majority of studies found that there was an influence about management practices on performance. Ahmed et al, (2018) Alabdullah et al, 2014, Alabdullah et al, (2021), Maqbool, and Zameer (2018) One of the most important findings of his research is that corporate social liability has a positive impact on the financial performance of Indian banks. Alabdullah et al, (2021), Airout, and Airout, (2017) The results indicate the existence of evidence of a relationship between sustainability and sustainability Financial performance sectors that are evaluated with the return on assets and stocks in Jordanian banks. Alharthi, (2017) and Alfadhl and Alabdullah, (2016, 2013) Where the study results indicated that banks in the Gulf Cooperation Council countries made good profits from their commitment to specific financial performance, which was in the Arab Spring crisis. Tarawneh, (2016), Almashhadani, 2020,2021a,2021b,2021c It is the most important of his findings That a bank that owns capital, deposits or trusts, and high financial performance makes better profits than banks that do not possess high ratios of assets and financial performance. Ahmed et al, (2019), AL-Fakhri and Alabdullah, (2021) and Salim, and Bilal, (2016) showed that the results of the research showed that there is no link between liquidity, whether long-term or short-term liquidity, management risks, investment status, and the bank's tolerance to financial shocks. Surprising as there is no indication of any relationship. Hassan Al-Tamimi, Miniaoui and Elkelish, (2015) The scores of this Research showed a positive link inter risk management and banks, which comes on top of capital risk. Thus, the hypothesis developed is

H1: A positive relationship between Risk Management Practice and Bank's Financial Performance.

\section{METHODOLOGY}

The current study is a cross-sectional based on a quantitative approach and the data collected was from annual reports. The units of analysis were the annual reports of the listed banks for 2020. Data was analyzed statistically via using the Partial Least Square (PLS) approach.

\section{Population and Sample size}

The population of this study is the banks listed in the Sultanate of Oman. The population size in this study consists of 8 banks. Therefore, the entire population was studied without taking smaller samples for the analysis. Given the small population frame of the study, census population techniques were employed to select the sample (Cooper \& Schindler, 2003).

Variables Measurements: The current research used a wide range of measurements of risks tools and banks outcomes. Each variable is illustrated as follows:

\section{Table 1. Variables Measurements}

\section{RESULTS AND DISCUSSION}

Based on the descriptive information that was obtained, the dependent variable, which is the International Valuation Standards (IVS), showed that 0\% represents a mean (IVS) with a standard deviation of 1.000 In addition, the minimum and maximum values indicated that (IVS) Was $-0.518,2.634$, Respectively, The results also showed that the return on assets reached $0 \%$, which represents the average support with a standard deviation of 1.000, Moreover, the minimum and maximum values indicate that the return on assets was -1.576 and 1.157 respectively, In addition, it shows the variable OF return on equity, which amounted to $0 \%$, which represents an average with a standard of deviations of 1.000 , moreover furthermore, the minimums and maximums of the values indicated that the return on equity amounted to -0.859 and 2.327, Respectively.

\section{Table 2: Descriptive Statistics of Variables}

\section{Discriminant Validity}

In PLS for testing of the Special validity, there are standards used. The square root of every AVE for every construct must have a high correlation level It includes the other constructs. Thus, to deal with discriminant validity, as mentioned by Fornell \& Larcker (1981), the square root of each construct in 
its AVE has to be compared versus the constructs' correlations for all other constructs.

\section{Table 3: Discriminant Validity}

The structural model was evaluated after analyzing the measurement model and passing all criteria. The coefficient of determination $\left(\mathrm{R}^{2}\right)$ is checked. In this work, the variable that is the internal supply has an $\mathrm{R}^{2}$ value of 0.283 (ROA), 0.811 (ROE) (large) indicating that $28 \%, 81 \%$ of the contrast in company performance (ROE and ROA) that can be elucidated by the predictors: variables were used in this Research (return on assets, capital adequacy, return on equity, risk credit, size of the bank) to measure the impact of risk management on this financial of performance of banks (ROA, ROE). So, the current of works greatly meets the standard.

\section{Table 4: Explanation of the Variance}

\section{Hypothesis Testing}

Table 5, reviews the results related to the supported hypothesis test as shown in Table 5. The results revealed that risk management is positively meaningful while avoiding risk as it was (ROA) $\mathrm{P}<0.000, \mathrm{t}=4.580$. The findings revealed that the risk management was insignificant with an ROE where it was $\mathrm{t}=1.306$. This score indicates if the management has a significant influence on Banks performance (ROA).

\section{$\underline{\text { Table 5: Path Coefficients }}$}

\section{Impact Of Risk Management on Financial Performance}

The management of banking risks has become a basic topic, as a basis for dealing with many negatives in banking and financial activities. The practice of risk management and control keeps banks away from risks such as liquidity, credit, and others. Risk management at the banking level aims to manage business risk and control risk. Commercial risks are those risks that are considered to be inherent in the bank's business nature. Control risk arises from insufficient control exercise or the possibility of failure and disruptions in the current control process of the bank.

Risk management has been identified in this research that affects equity, which is the independent variables (capital adequacy, credit risk, bank size, operational risk agent, liquidity risk agent) and their impact on banks performance (ROA and ROE). From the independent variables recognized, Hypotheses were developed to enquire about the target. The study used the quantitative data obtained from the Muscat Securities Market website for the fiscal year 2021, and eight Omani banks were collected. The results related to the supported hypothesis test as shown in Table 5. The results revealed that risk management is a positive and significant link with financial performance as it was $(\mathrm{ROA}) \mathrm{P}<0.000, \mathrm{t}=$ 4.580. This result indicates that management has a significant influence on Banks. These findings are consistency with the study done by Alabdullah, (2017), Alabdullah, (2016a),
Hassan Al-Tamimi, Miniaoui and Elkelish, (2015). They showed a strong association between risk management and banks performance. This means more managing the risk will lead to reducing the risk and will increase the financial performance. As well, the results found an insignificant link between risk management with Return on equity.

\section{CONCLUSION}

To conclude, the main aim of this investigation is to study the association between risk of management practices and the financial performance of banks in the MSM, which was limited to the past five years. In addition, five variables were used in this study (return on equity, return on assets, adequacy capital, credit risk, bank size) to measure the impact of risk management on the financial performance of banks (ROA, ROE). Data was collected from eight banks in Oman. The results showed a positive link inter risk management and financial performance. Moreover, findings found that there is no connection between risk management with Return on equity. Implications

This research is new to be applied in the Oman context via investigating the relation between its predictors of risk management practices towards their impact on financial performance. The current study contributes and fills the gap found in the literature review by providing practical and theoretical implications. A theoretical contribution based on risk management by proposing some practices as essential predictors of risk management. In that, this study utilized in the current research as a theoretical foundation for the suggested conceptual framework of the current study. Besides its theoretical contribution, the current research presents a more practical understanding of the key practices that should be considered in applying risk management. For an instant, considerable attention should be given to the role of the risk management committee regarding their positive impact on performance.

\section{REFERENCES}

Abushammala, S. N., Alabdullah, T. T. Y., \& Ahmed, E. R. 2015. Causal Relationship between Market Growth and Economic Growth. Comparison Study. European Journal of Business and Management 7(33), 31-36.

Ahmed, E. R., Islam, M. A., Alabdullah, T. T. Y., and bin Amran, A. 2018c. Proposed the pricing model as an alternative Islamic benchmark. Benchmarking: An International Journal 25, 2892-2912. doi: 10.1108/bij-042017-0077.

Ahmed, E. R., Alabdullah, T. T. Y., Ardhani, L., \& Putri, E. 2021. The Inventory Control System's Weaknesses Based on the Accounting Postgraduate Students' Perspectives. Journal of Accounting and Business Education, 5(2), 1-8.DOI: http://dx.doi.org/10.26675/jabe.v5i2.19312.

Ahmed, E. R., Abdul Rahim, N. F., Alabdullah, T. T. Y \& Thottoli, M. M. 2019. An Examination of Social Media Role in Entrepreneurial Intention among Acounting Students: A SEM Study. Journal of Modern Accounting and Auditing, 15(12)

Ahmed, E. R., Alabdullah, T. T. Y \& Shaharudin, M. S. 2020. Approaches to Control Mechanisms and Their Implications for Companies' Profitability: a Study In

UAE. Journal of accounting Science, Vol. 4, no. 2, pp. 11-20.

Ahmed, E. R., Alabdullah, T. T. Y., Thottoli, M. M., \& Maryanti, E. 2020. Does Corporate Governance Predict Firm Profitability? An Empirical Study in Oman. The International Journal of Accounting and Business Society, 28(1), 127-143. 
Ahmed, E. R., Alabdullah, T. T. Y., Shaharudin, M. S., \& Putri, E. 2020. Further Evidence on the Link between Firm's Control Mechanisms and Firm Financial Performance: Sultanate of Oman. Journal of Governance and Integrity, 4(1), $1-6$

Ahmed, E. R., Alabdullah, T. Y., Islam, M. A., \& Asmar, M. 2014. Sukuk Legitimacy: A New Measurement Based on Content Analysis. 16th Malaysian Finance Association Conference in Sasana Kijang Central Bank of Malaysia, Kuala Lumpur, June 4-6, 2014.

Ahmed, E. R., Aiffin, K. H. B., Alabdullah, T. T. Y., \& Zuqebah, A. 2016. Zakat and Accounting Valuation Model. Journal of Reviews on Global Economics, 5, 16-24.

Ahmed, E. R., Islam, M. A., and \&amp; Alabdullah, T. T. Y. 2017. The moderating role of Shariah supervisory board on sukuk pricing benchmark. International Journal of Excellence in Islamic Banking and Finance 6.

Ahmed, E. R., Islam, A., Zuqibeh, A., \& Alabdullah, T. T. Y. 2014. Risks management in Islamic financial instruments. Advances in Environmenta Biology, 402-406.

Ahmed, E. R., Alabdullah, T. T. Y., Amran, A., \& Yahya, S. B. 2018. Indebtedness Theory and Shariah Boards: A Theoretical Approach. Global Business and Management Research, 10(1), 127-134.

Ahmed, E. R., A Amran, Alabdullah, T. T. Y., \& , A Islam 2019. Testing The Legitimacy Index In Light Of Shariah Risks For Sukuk Markets. European Proceedings of Social and Behavioural Sciences 88.

Alabdullah, T. T. Y. 2017. Compensation committee, company board attributes, and company performance: The moderating effect of leadership position. Paper presented at the 2017 Wei International Academic Conference Proceedings, July 24-27, 2017, Business and Economics.

Alabdullah, T. T. Y. 2016a. Are Board Size And Ownership Structure Beneficial In Emerging Markets' Firms? Evidence from Jordan. International Journal of Management \& Information Systems (IJMIS), 20(3), 87-94.

Alabdullah, T. T. Y. 2021. Ownership Structure and the Failure or Success of Firm Performance: Evidence from Emerging Market; Cross-sectional Analysis, International Journal of Business and Management Invention, Volume 10 Issue 8, pp17-20.

Alabdullah, T. T. Y. 2016b. Agency Theory Perspective: A Quantitative Study Of Accounting Performance Measures In Emerging Economies. ICTE Proceedings, New York.

Alabdullah, T. T. Y. 2016c. Corporate Governance from The Perspective of The Past and The Present and The Need to Fill an International Gap. Risk Governance \& Control: Financial Markets \& Institutions, 6(4).

Alabdullah, T. T. Y., Ahmed, E. R., Almashhadani, M., Yousif, S. K., Almashhadani, H, A., Almashhadani, R., Putri, E. 2021. How significantly to emergingeconomies benefit from board attributes and risk management in enhancing firm profitability? Journal of accounting Science, Vol. 5, no. 1

Alabdullah, T. T. Y. 2019. Management Accounting and Service Companies' Performance: Research in Emerging Economies, Australasian Accounting, Business and Finance Journal, 13(4), 2019, 100-118. doi:10.14453/aabfj.v13i4.8.

Alabdullah, T. T. Y. 2021. Management accounting insight via a new perspective on the risk management - companies' profitability relationship. International Journal of Intelligent Enterprise 7, In press.

Alabdullah, T. T. Y. 2016d. The Performance of Companies and The Board's Characteristics From the New Perspective of Manipulation Avoidance. Corporate Ownership \& Control, 13(4), 279-286.

Alabdullah, T. T. Y., Yahya, S., and T.Ramayah. 2014a. Corporate Governance Mechanisms and Jordanian Companies' Financial Performance. Asian Social Science 10, 247-247.

Alabdullah, T. T. Y., Yahya, S., \& Ramayah, T. 2014b. Corporate Governance Development: New or Old Concept? European Journal of Business and Management, 6(7), 312-315.

Alabdullah, T. T. Y., Alfadhl, M. M. A., Yahya, S., \& Rabi, A. M. A. 2014. The Role of Forensic Accounting in Reducing Financial Corruption: A Study in Iraq. International Journal of Business and Management, 9 (1), 26.

Alabdullah, T. T. Y. 2018. The relationship between ownership structure and firm financial performance. Benchmarking: An International Journal, 25(1), 319333.

Alabdullah, T. T. Y., Maryanti, E . 2021. Internal Control Mechanisms in Accounting, Management, and Economy: A review of the Literature and Suggestions of New Investigations. International Journal of Business and Management Invention, 10(9)

Alabdullah, T. T. Y., Ahmed, E. R. 2021. New Insights to Investigate the Impact of Internal Control Mechanisms on Firm Performance: A Study in Oman. Riset Akuntansi dan Keuangan Indonesia, Vol. 6,(2).

Alabdullah, T. T. Y., \& Ahmed, E. R. 2020. A cross-sectional analysis of the influence of corporate governance features on the organizational outcomes: An assessment. IIUC Studies, 9-26.

Alabdullah, T. T. Y., Ahmed, E. R., \& Ahmed, R. R. 2021. Organization features and profitability: Implications for a sample of Emerging Countries. Journal of Accounting and Business Education, 5(2), 43-52.DOI: http://dx.doi.org/10.26675/jabe.v5i2.16351

Alabdullah, T. T. Y., Yahya, S., Nor, M. I., \& Majeed, F. Q. 2016. An Investigation of Corporate Governance from A New Perspective: Examining the Financial Performance of Companies and The Impact of Executive Turnover. Corporate Board: Role, Duties \& Composition, 12(1).

Alabdullah, T. T. Y., Ahmed, E. R. 2019. Board Diversity and Disclosure of Corporate Social Responsibility Link: A Study in Malaysia. Journal of Adv Research in Dynamic \& Control System, 11(11).

Alabdullah, T. T. Y., Ahmed, E. R., \& Muneerali, M. 2019. Effect of Board Size and Duality on Corporate Social Responsibility: What has Improved in Corporate Governance in Asia?. Journal of Accounting Science, 3(2), 121-135.

Alabdullah, T. T. Y., Laadjal, A., Ries, E., \& Al-Asadi, Y. A. A. 2018. Board Features and Capital Structure in Emerging Markets. Journal of Advanced Management Science, 6 (2).

Alabdullah, T. T. Y., Nor, M. I., \& Ahmed, E. R. 2018. The determination of firm performance in emerging nations: Do board size and firm size matter? Management, 5(3), 57-66.

Alabdullah, T. T. Y., Ahmed, E. R., and Nor, M. I. 2020. The World Declining Economy And Coronavirus Pandemic: Systems Should Be Continued. Russian Journal of Agricultural and Socio-Economic Sciences 102, 89-96. doi: 10.18551/rjoas.2020-06.11.

Alabdullah, T. T. Y \& Ahmed, E. R. 2020. Audit Committee Impact on Corporate Profitability in Oman Companies: an Auditing and Management Accounting Perspective. Riset Akuntansi dan Keuangan Indonesia, Vol. 5, no. 2, pp. 121 128.

Alabdullah, T. T. Y \& Ahmed, E. R. \& Abushammala, S. 2020. Growth of Companies: Empirical Study of the Companies Listed in Developing Economies. Journal of accounting Science, Vol. 4, no. 2, pp. 1-10.

Alabdullah, T. T. Y., Ahmed, E. R., \& Nor, M. I. 2019. Do board characteristics provide more enhancement for firm financial performance? A corporate governance perspective. New challenges in corporate governance: Theory and practice (pp. 89-91). https://doi.org/10.22495/ncpr_25.

Alabdullah, T. T. Y., Ahmed, E. R., \& Nor, M. I. 2018. New Ideas from Management, Finance and Accounting Perspective: The Research for A New Link Between A Company's Outcome and Risk Management. 5th International Conference on New Ideas in Management, Economics and Accounting.

Alabdullah, T. T. Y. and Ahmed, E. R. 2018. Corporate Governance: To What Extent it is important in the Arab Countries. International Journal of Science and Research 7.

Alabdullah, T. T. Y., Al-Fakhri, I., Ahmed, E. R., \& Kanaan-Jebna, A. 2021. Empirical Study Of The Influence Of Board Of Directors'feature On Firm Performance. Russian Journal of Agricultural and Socio-Economic Sciences. 11(119), 137-146.

Alfadhl, M. M. A., Alabdullah, T. T. Y. 2016. Agency Cost and Management Behavior: The Role of Performance as a Moderator. International Journal of Science and Research (IJSR), 5(1), 1858-1864.

Alfadhl, M. M. A. F. and Alabdullah, T. T. Y. 2013. Determinants of the Managerial Behavior of Agency Cost and Its Influential Extent on Performance: A Study in Iraq. International Journal of Humanities and Social Science, 3-3.

Alia, B. J., \& Oudatb, M. S. 2020. Financial Risk and the Financial Performance in listed Commercial and Investment Banks in Bahrain Bourse. International Journal of Innovation, Creativity and Change, 13(12), 160-180

Almashhadani, M. 2021a. How Dose Corporate Governance Leverage Organizational Performance: A Survey With Suggestions And Notes For Further Research. Russian Journal of Agricultural and Socio-Economic Sciences 3(111), 3-9.

Almashhadani, M. 2021b. Internal Control Mechanisms, CSR, and Profitability: A Discussion. International Journal of Business and Management Invention, 10(12), 38-43.

Almashhadani, M. 2021c. A brief Review of Corporate Governance Structure and Corporate Profitability in Developed and Developing economy: A review. 
International Journal of Business and Management Invention, 10(11), 42-46.

Almashhadani, M. 2020. Testing the effecting elements of R\&D engineer's inventively in design industrialization Sector: A study in Singapore. Journal of Information and Computational Science,10(5).

Alsulmani, A. H., Alkindi, S. S., \& Ahmed, E. R. 2021. Customer Accounting Information and Omani Service Companies' Performance. International Journal of Finance \& Banking Studies (2147-4486), 10(2), 79-88.

Alyaarubi, H. J., Alkindi, D. S., \& Ahmed, E. R. 2021. Internal Auditing Quality and Earnings Management: Evidence from Sultanate of Oman. Journal of Governance and Integrity, 4(2), 115-124.

Azam, S. T. 2019. The Impact of Credit Risk on the Financial Performance of Commercial Banks in Bangladesh.

Asaduzzaman, M., \& Chowdhury, T. 2014. Effect of working capital management on firm profitability: Empirical Evidence from textiles industry of Bangladesh. Research Journal of Finance and Accounting, 5(8), 175-184.

Alharthi, M. 2017. Financial performance and stability in Islamic banks: Evidence from GCC countries. Corporate Ownership and Control, 14(4), 103-113.

Alfadli, A., \& Rjoub, H. 2020. The impacts of bank-specific, industry-specific and macroeconomic variables on commercial bank financial performance: evidence from the Gulf cooperation council countries. Applied Economics Letters, 27(15), 1284-1288.

AL-Fakhri, I., Alabdullah, T.T.Y. 2021. The Evolution of a Robust and Reliable Brand Experience Scale in the Malaysian Context: An Empirical Evidence. Business Ethics and Leadership, 5(4), 5967. https://doi.org/10.21272/bel.5(4).59-67.2021

Almagtome, A., \& Abbas, Z. 2020. Value relevance of financial performance measures: An empirical study. International Journal of Psychological Rehabilitation, 24(7), 6777-6791.

Airout, R. M., \& Airout, R. M. 2017. Evaluation of Financial Performance of Islamic Banks in Jordan (2001-2010): A Comparative Study. International Journal of Economics and Finance, 9(9), 166-174.

Al Siyabi, A. M. M. N., Al Araimi, S. M. M., \& Pandey, J. 2019. An investigation of risk management practices in electronic banking in Sultanate of Oman. Journal of Student Research.

Bilal, Z. O., \& Salim, B. F. 2016. Does Basil III Implementation Impact on Financial Performance?. Evidence from Omani's Commercial Banks. International Journal of Economics and Financial Issues, 6(3).

Cooper, R. \& Schindler, P. 2003. Business research method (8th ed). Boson: McGraw-Hill Irwin.

Dzapasi, F. D. 2020. The impact of Liquidity Management on Bank Financial Performance in a subdued economic environment: A case of the Zimbabwean Banking Industry. PM World Journal, 9(1), 1-20.

Darwish, S., \& Abdeldayem, M. M. 2019. Risk Management and Business Ethics: Relations and Impacts in the GCC. International Journal of Civil Engineering and Technology, 10(10), 489-504.

Essia Ries, A. 2014. Islamic Sukuk: Pricing mechanism and rating [Електронний pecypc]/Essia Ries Ahmed, Md. Aminul Islam, Tariq Tawfeeq Yousif Alabdullah. Journal of Asian Scientific Research, (4), 11.

Falih Chichan, H., \& Alabdullah, T. T. Y. 2021. Does Environmental Management Accounting Matter in Promoting Sustainable Development? A study in Iraq. Journal of Accounting Science, 5(2), 114-126.

Gani, A. A. M. O., Al Rahbi, A. H. S. S., \& Ahmed, E. R. 2021. Empirical Analysis on Corporate Transparency, Competitive Advantage, and Performance: An Insight of Muscat Securities Market. Journal of Governance and Integrity, 4(2), 96-102.

Galdeano, D., Ahmed, U., Fati, M., Rehan, R., \& Ahmed, A. 2019. Financial performance and corporate social responsibility in the banking sector of Bahrain: Can engagement moderate? Management Science Letters, 9(10), 1529-1542.

Harash, E., Alsaad, F. J., \& Ahmed, E. R. 2013. Moderating effect of market practices on the government policy-Performance relationship in Iraq SMEs. American Journal of Economics, 3(5), 125-130.

Hashim, F., Ries, E. A., \& Huai, N. T. (2019). Corporate Social Responsibility and Financial Performance: The Case of ASEAN Telecommunications Companies. KnE Social Sciences, 892-913.

Hassan Al-Tamimi, H. A., Miniaoui, H., \& Elkelish, W. W. (2015). Financial risk and Islamic banks' performance in the Gulf Cooperation Council Countries. The International Journal of Business and Finance Research, 9(5), 103-112.

Kanaan-Jebna, A., Baharudi, A. S., \& Alabdullah, T. T. Y. (2022). Entrepreneurial Orientation, Market Orientation, Managerial Accounting and Manufacturing
SMEs Satisfaction. Journal of Accounting Science, 6(1), 1-14.

Maqbool, S., \& Zameer, M. N. 2018. Corporate social responsibility and financial performance: An empirical analysis of Indian banks. Future Business Journal, 4(1), 84-93.

Nomran, N. M., \& Haron, R. 2019. Dual board governance structure and multi-bank performance: a comparative analysis between Islamic banks in Southeast Asia and GCC countries. Corporate Governance: The International Journal of Business in Society.

Nor, M. I., Masron, T. A., \& Alabdullah, T. T. Y. 2020. Macroeconomic fundamentals and the exchange rate volatility: empirical evidence from Somalia. SAGE Open, 10(1), 2158244019898841.

Olamide, O., Uwalomwa, U., \& Ranti, U. O. 2015. The Effect of Risk Management on Bank's Financial Performance in Nigeria. Journal of Accounting and Auditing, 2015, 1.

Ogboi , Unuafe , 2013. Impact of credit risk management and capital adequacy on the financial performance of commercial banks in Nigeria. Journal of emerging issues in economics, finance and banking, 2(3), 703-717.

Pakurár, M., Haddad, H., Nagy, J., Popp, J., \& Oláh, J. 2019. The impact of supply chain integration and internal control on financial performance in the Jordanian banking sector. Sustainability, 11(5), 1248.

Rao Al-Yahyaee \& Syed, L. A. 2007. Capital structure and financial performance: evidence from Oman. Indian Journal of Economics and Business, 6(1)

Salim, B. F., \& Bilal, Z. O. 2016. The impact of liquidity management on financial performance in Omani banking sector. International Journal of Accounting, Business and Economic Research, 14(1), 545-565.

Singh, K. S. D., Islam, M. A., Ahmed, E. R., \& Amran, A. 2019. An empirical investigation into the major drivers of corporate social responsibility. Opción, 35, 1076-1090.

Sleimi, M. 2020. Effects of risk management practices on banks' performance: An empirical study of the Jordanian banks. Management Science Letters, 10(2), 489-496.

Sukmana, R., Ajija, S. R., Salama, S. C. U., \& Hudaifah, A. 2020. Financial performance of rural banks in Indonesia: A two-stage DEA approach. Heliyon, 6(7), e04390

Tarawneh, M. 2016. A comparison of financial performance in the banking sector: Some evidence from Omani commercial banks. International Research Journal of Finance and Economics, 3(3), 101-112.

Thottoli, M. M., Thomas, K. V., \& Ahmed, E. R. 2019a. Qualitative analysis on information communication technology and auditing practices of accounting professionals. Journal of Information and Computational Science, 9(9), 529537.

Thottoli, M. M., Thomas, K. V., \& Ahmed, E. R. 2019b. Adoption of audit software by audit firms: a qualitative study. Journal of Information and Computational Science, 9(9), 768-776.

Thottoli, M. M., Thomas, K. V., \& Ahmed, E. R. 2019c. Examining the impact of information communication technology on auditing professionals: A quantitative study. Journal of Advanced Research in Dynamical and Control Systems, 11(12), 476-488.

Thottoli, M.M. and Ahmed, E.R. 2021, "Information technology and E-accounting: some determinants among SMEs", Journal of Money and Business, Vol. aheadof-print No. ahead-of-print. https://doi.org/10.1108/JMB-05-2021-0018

Conflict of InterestStatement:Theauthorsdeclare that the research wasconducted in the absence of any commercial or financial relationships that could be construed as a potential conflict of interest.

Copyright (C) 2022 and. This is an open-access article distributed under the terms of the Creative Commons Attribution License (CC BY). The use, distribution or reproduction in other forums is permitted, provided the original author(s) and the copyright owner(s) are credited and that the original publication in this journal is cited, in accordance with accepted academic practice. No use, distribution or reproduction is permitted which does not comply with these terms. 


\section{LIST OF TABLES}

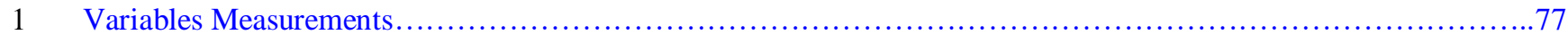

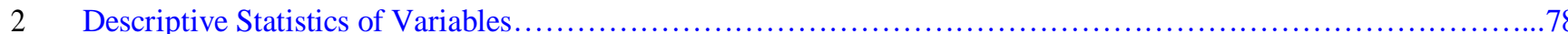

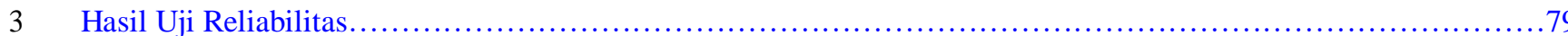

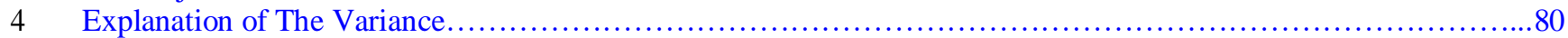

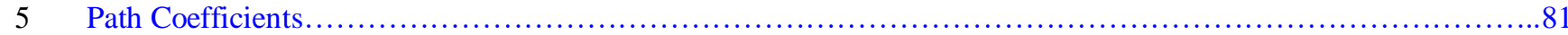


TABLE1/Variables Measurements

Variables

Return on Equity

Return on Assets

Proxy of operational risk

Proxy of liquidity risk
Measurement

Net profit/total Equity

Net profit/total assets

Operational costs/Net interest income

POR

PLR

Total loans/ total deposit 
TABLE 2 / Descriptive Statistics of Variables

\begin{tabular}{|c|c|c|c|c|}
\hline & Mean & Min & $\operatorname{Max}$ & Standard Deviation \\
\hline Risk Management Practices & 0.000 & -0.518 & 2.634 & 1.000 \\
\hline Return on Assets & 0.000 & -1.576 & 1.157 & 1.000 \\
\hline Return on Equity & 0.000 & -0.859 & 2.327 & 1.000 \\
\hline
\end{tabular}


TABLE 3 / Hasil Uji Reliabilitas

\begin{tabular}{|c|c|c|c|c|c|c|c|}
\hline & CIP & EA & LLPTL & LNASSETS & LTDR & ROA & ROE \\
\hline CIP & 1.000 & & & & & & \\
\hline EA & -3.345 & 1.000 & & & & & \\
\hline LLPTL & 0.054 & 0.166 & 1.000 & & & & \\
\hline LNASSETS & -0.037 & -0.605 & 0.036 & 1.000 & & & \\
\hline LTDR & 0.126 & -0.813 & -0.066 & 0.945 & 1.000 & & \\
\hline ROA & 0.214 & 0.142 & 0.087 & -0.700 & -0.575 & 1.000 & \\
\hline ROE & 0.211 & -0.836 & -0.342 & 0.806 & 0.885 & -0.513 & 1.000 \\
\hline
\end{tabular}


TABLE 4 / Explanation of The Variance

\begin{tabular}{|c|c|c|}
\hline & R Square & R Square Adjusted \\
\hline Return on Assets & 0.386 & 0.283 \\
\hline Return on Equity & 0.838 & 0.811 \\
\hline
\end{tabular}


TABLE 5 / Path Coefficient

\begin{tabular}{|c|c|c|c|c|c|c|}
\hline \multicolumn{7}{|c|}{ Mean, STDEV, T-Values, P-Values } \\
\hline & Original Sample (O) & Sample Mean (M) & $\begin{array}{l}\text { Standard Deviation } \\
\text { (STDEV) }\end{array}$ & T Statistics & $P$ Values & Results \\
\hline RM-> Return on Assets & -0.621 & -0.746 & 0.136 & 4.580 & 0.000 & Supported \\
\hline RM $>>$ Return on Equity & 0.916 & 0.483 & 0.701 & 1.306 & 0.097 & Rejected \\
\hline
\end{tabular}

Note: Significance levels: $* * * \mathrm{P}<0.001(\mathrm{t}>3.33),{ }^{*} \mathrm{p}<0.01(\mathrm{t}>2.33),{ }^{*} \mathrm{p}<0.05(\mathrm{t}>1.605)$ 


\section{LIST OF TABLES}

1 Research Framework 
FIGURE 1 / Research Framework

\begin{tabular}{|l|l|}
\hline Independent Variable & Dependent Variable \\
\hline $\begin{array}{l}\text { Risk Management } \\
\text { Practices }\end{array}$ & Financial Performance \\
\hline
\end{tabular}

